\title{
A Painting and A Slave Ship: Ruskin's Visual Narrative on Turner
}

\author{
DR. ÖĞR. ÜYESI ASYA SAKINE UÇAR*
}

\begin{abstract}
Thanks to his technique of 'word painting' and employing words to replicate what viewing a painting feels like, John Ruskin is actively engaged in associations between word and image. Ruskin admired Joseph Mallord William Turner's works as the painter also used his own poetry as subsidiary to his paintings. The fact that both artists are inspired by sister arts, poetry and painting has been long debated. Yet as Turner tried to syncretize his painting with poetry and Ruskin tried to render visual proses, they still remained aware of both the union and the gap between words and images. What Turner did with his visual narratives is communicating on a level that required spectators' commitment and engagement. For that reason, Ruskin's defense and advocacy of William Turner in Modern Painters through Slavers Throwing Overboard the Dead and Dying - Typhoon Coming On (1840), or The Slave Ship, suggests a special example in relating both artists to each other as much visually as poetically and verbally. In that sense, the aim of this article is to manifest how Turner's highly abstract composition that initially met with a great deal of negative reaction but came to function as a medium for reflection of greater depth on the horrors of slavery with a historical particularity could be discovered through revisiting Ruskin's sublime, ekphrastic elaborations.
\end{abstract}

Keywords: Ruskin, Turner, word, image, visual, The Slave Ship, ekphrasis

\section{BİR RESIM VE BİR KÖLE GEMISİ: RUSKİN’İN TURNER ÜZERINNE GÖRSEL ANLATISI Öz}

Ruskin'in âdeta bir tabloya bakmanın bıraktığı izlenimleri anımsatan sözlü görselleri, onu sözcük ve imge temalı tartışmalarda öne plana çıkarmıştır. Ruskin, Joseph Mallord William Turner'ın resimlerine eşlik etmesi için şiir kullanmasını takdir etmiştir. Her iki sanatçının da kardeş sanatlar olan resim ve şiirden etkilenmiş olmaları hep tartışılan bir konu olmuştur. Turner resimlerine şiiri entegre etmeye çalışırken Ruskin görsel yazına yönelmiş ancak her ikisi de söz ve imge arasındaki birliğin ve farkın bilincinde kalmıştır. Turner görsel anlatılarında izleyicilerin de iştirakını ve sadakatini gerektiren bir iletişim yolunu seçmiştir. Bu nedenle Ruskin'in Modern Ressamlar'da özellikle Köle Gemisi olarak da bilinen Slavers Throwing Overboard the Dead and Dying - Typhoon Coming On (1840) eseri üzerinden Turner'1 yüceltmesi ve savunması her iki sanatçıyı görsel olduğu kadar şiirsel ve sözel olarak da birbiriyle ilişkilendiren bir örnek sunar. Dolayısıyla bu makalenin amacı, Turner'ın önce olumsuz tepkilere neden olan fazlasıyla soyut kompozisyonunun zamanla tarihsel bir gerçeklikle köleliğin korkunçluğu üzerine daha derin bir yansıma işlevi gören bir temsile dönüşmesinin Ruskin'in ekfrastik, sublime betimlemeleri sayesinde keşfedilebileceğini göstermektir.

Anahtar sözcükler: Ruskin, Turner, söz, imge, görsel, Köle Gemisi, ekfrasis

\footnotetext{
* Iğdır Ün. Fen-Edebiyat Fak. İngiliz Dili ve Edebiyatı, ucar.as@yahoo.com, orcid: 0000-0002-9653-2911 


\section{MAIN BODY}

The practice of describing works of art is rooted in antiquity as the Greek coined the term ekphrasis which was initially an exercise for orators and then grew into a genre.

1 As a term, the closest to modern use of ekphrasis is believed to have been mentioned by Simonides of Ceos who is known for his motto "painting is mute poetry and poetry is speaking picture". After him, Horace in his Ars Poetica declared one of his most famous dictums "ut pictura poesis" (as is painting so is poetry). Ekphrasis offers a means of imagining sights re-created, veiled, obstructed, idealized, and even unseen. It could occur before a known sculpture whose story arouses both mystery and emotion. Or it might be a frightening incident set in a landscape recognizable as an established painting whose colours, lighting, perspective or brushstroke bring a definite image and mood to the reader. In drawing the reader's attention to the visual, ekphrasis is first about the act of seeing. While centering upon the context of such seeing within verbal ideas, sight becomes insight, leading to knowledge, procuring the mind to understand both the concrete and the abstract idea. The speaking picture or that visual perception is a spectacle of those kinds of historical and theoretical study that focus on the interrelations between the visual arts and literature.

The rhetorical, aesthetic and ideological principles behind words and images are inseparably interwoven for John Ruskin whose influence on the entire artistic generation of Pre-Raphaelite Brotherhood, represent a pertinent "ut pictura poses" example and a concrete application of ekphrasis tradition as he illustrated his own writings.

“Throughout Ruskin's life and work, the visual informed the verbal. His subject was the visual world: the elements of nature framed by landscape, the human shaping of those elements into architecture, and human response to them expressed in sculpture and painting. With all aspects of the visible, Ruskin's analysis equally was visual, through the practice of drawing at which he excelled. Images of the external world also shaped the internal operation of his imagination and molded his prose. Many of his arguments were governed by images that relate to each other as much visually as poetically or logically. His intellectual and emotional life was formed by visual experiences in front of specific paintings". (Whelchel, 1993, p. 29)

Ruskin's great work Modern Painters had its seed in the essay written in defense of Turner. By singling out Turner for special 'superiority' he further antagonized many who, whilst cognizant of that painter's genius, nevertheless experienced difficulty in apprehending his more experimental work (Bradley,1995, p. 6). Beginning in 1843 with the first volume of Modern Painters, continuing through his publications of the 1840s and 1850s, and culminating in I860 in the fifth volume of Modern Painters, Ruskin argued for a very particular interpretation of Turner (Munsterberg, 2009, p. 61). While the first volume of Modern Painters attempts to prove that Turner was the most truthful painter of landscapes, "the role of the second is in part to present an aesthetic theory in relation to which Turner's paintings could appear as not only the most truthful but the most beautiful creations of English art" (Landow, 2015, p. 89). According to Hunt, what unites Ruskin and Turner is that "the example of Turner's own use of elaborate titles and catalogue entries for his pictures was one that Ruskin inevitably took seriously" (1978, p. 802). 
Turner's long, detailed titles were actually at odds with his desire to paint what he saw rather than what he knew as his career is often marked with the importance he assigned to nature and the unity of arts helped him to find the heightened expression he desired and sought.

The formulation of poetic painting and painterly prose is within the realm of paragone discussions which refers to the rivalry between poetry and painting in art-historical context. The fact that verse and visual arts are analogous was a widely held theory and relied heavily on the support of Simonides or Horace. The recurring debates between sister arts throughout history also necessitate the spectators' active participation in reconciling the discrepancy between words and images. Yet, even the earliest manifestations point to a hierarchical position, and mostly painters being relegated to an inferior status because of the mimetic nature of their art. Indeed, Turner, who considered himself a poet as well as a painter and his greatest supporter in this venture, the critic John Ruskin, were actively involved in building new connections between word and image.

"Ruskin and Turner each turned to the sister arts both for inspiration, and importantly, for a means of supplementing what each perceived to be the insufficiencies of his own medium. For Turner, painting's concrete, mimetic nature was at odds with his desire to communicate abstract ideas, while for Ruskin, language's abstract and conventional nature fell short of our visual experience of the world and failed adequately to address our visual powers of thought, memory, and imagination". (Wettlaufer, 2000, p. 149-150)

What William Turner did with his visual narratives is communicating on a similar level which offers an important route into exploration of Ruskin's conviction about the greatness of Turner's work and efforts to overcome the objections that his abstract compositions appear incomprehensible. Turner's poetical efforts do not just manifest his interest in sister arts but it is also inseparable from 18th and 19th century discussions on the roles and distinctions of several arts (Ziff, 1964, p. 195). "Turner marked an important break with the linear formalism of contemporary academic painting and embraced an aesthetic that privileges colour, movement, expression and imagination over strict mimetic fidelity" (Wettlaufer, 2003, p. 198), moving towards abstraction and indirection in his compositions. While abstraction of landscapes meant aesthetic detachment and even met antagonism and degradation, his canvases or visual transcriptions are tempered by a poetic essence extending physical dimensions. Likewise, Ruskin's visual language in Victorian Age clearly had its inspiration from classical tradition and rhetoric in particular and attempted to include the readers by turning them into spectators. Ruskin suggests painting as analogous to poetry and the two words can be used interchangeably yet he bemoans the difficulty of translating Turner's sublime visual art into language. For that reason, in characterizing Ruskin's language of description, the famous observation "word-painting" is often expanded upon.

In Modern Painters I, Ruskin discovered a new way of writing about paintings which meant placing the viewer before it. While a painter can turn to poetry for theoretical inspiration, a poet's verbal imagination can be transmitted to the readers through visual images. For him, picturesque required verbal elaboration and there is a necessity for an alliance between word and image. Unwilling to write simple description, "he used metaphors for selected parts of the image to serve his projection of the painting's emotional impact" (McCoubrey, 1998, p. 347). Such word paintings, demonstrate his strategy of drawing a detailed framework giving attention to colours and shaping 
a dynamic narrative with plentiful verbs and adjectives as in the example of The Slave Ship. That single moment captured in the picture is added a new dimension with Ruskin's sublime depiction.

"But I think, the noblest sea that Turner has ever painted, and if so, the noblest certainly ever painted by man, is that of the Slave Ship, the chief Academy picture of Exhibition of 1840. It is a sunset on the Atlantic after prolonged storm; but the storm is partially lulled, and the torn and streaming rain-clouds are moving in scarlet lines to lose themselves in the hollow of the night. The whole surface of sea included in the picture is divided into two ridges of enormous swell, not high, nor local, but a low, broad heaving of the whole ocean, like the lifting of its bosom by deep drawn breath after the torture of the storm. Between these two ridges, the fire of the sunset falls along the trough of the sea, dyeing it with an awful but glorious light, the intense and lurid splendor which burns like gold and bathes like blood". (Ruskin, 1858, p. 376)

Ruskin begins sketching the general atmosphere of the scene drawing attention to the usage of colours and light, giving prominence to Turner's artistic abilities. Ruskin employs a large amount of verbs and adjectives constituting a completely dynamic narrative, appealing to all senses helping the readers to bring the scene before the eyes with an ekphrastic approach. For Döring, "the painting derives its power and effect through the visual rhetoric of the sublime", it "invests in the iconography of the slave trade while at the same time, engaging the beholder's eye with an ecstasy of light and colour culminating in the central image of a blindingly white sun" (1997, p. 4). Contemplating the greatness of noble things produces elevation of mind and anything which elevates the mind is sublime. In outlining Ruskin's theory of art, what should not go unnoticed is the fact that the beautiful or any other forms of pleasure, greatness is not distinct from the conception of sublime which is a dominant concern of aesthetic speculation for Turner, too. Ruskin claims that before Turner, landscape painters

“(...) may have amused the intellect, or exercises the ingenuity, but they never have spoken to the heart. Landscape art has never taught us one deep or holy lesson; it has not recorded that which is fleeting nor penetrated that which was hidden, nor interpreted that which was obscure..." (1903, p. 21-22).

From a hermeneutical viewpoint, the ambivalence associated with Romanticism, might be an efficient tool in understanding Turner as a modern Romantic artist. According to Giampiero Moretti, this very essential ambiguity plays a role in the poetical consciousness of time and in his own words, "there exists a profound link between Ruskin's intention to defend Turner from his detractors, the uniquely Romanticist nexus between ambiguity and modernity, and the Romanticist/Turnerian fondness for 'nature' “(2016, p. 4). For Ruskin, Turner is the most truthful landscape painter and that truth "as 'natural' manifestation (not simply nature's) is both a fluctuation between a human being's individual and fragmentary sentiment and the divine as the hidden and truly infinite force that pervades the manifestation of every natural phenomenon" (Moretti 8). Infinite, as an essential Romanticist term allows to point it out as sublime infinite. According to Wettlaufer, "at the heart of Turner's sibling rivalry with the sister art then lay his ending search for access to the realm of abstract meaning" (2000, p. 155) and this is more clearly portrayed in the sublime. 
In depicting shipwrecks, storms at sea, and other sublime subjects, Turner often addressed the viewer with frightening immediacy... (McCoubrey, 1998, p. 322). In his book Turner and the Sublime, Andrew Wilton says:

"...the direct representation of human life is reduced to an expressive minimum, the overpowering atmosphere achieved by the most emphatic statement of the natural effects of sunset and brooding storm cloud. Turner aims unambiguously at the sublime, reproducing with all his skill a stupendous natural phenomenon in order to impress us with the larger argument of his picture". (1980, p. 98)

The destructiveness of the sea, storm, mist, and smoke are correlated with the power, magnificence, obscurity, awe and more importantly Turner creates a dynamic composition that involves spectators who cannot resist relating themselves to the scene or being struck by the impact of the darkened, emotional ambience. Judith Fisher point out that Turner painted primarily to satisfy his own explorations into the actions of light in the atmosphere. He kept his pigments pure, juxtaposing them on canvas rather than mixing them on the palette so that the viewer's eye fused them (1996, p. 249). For some, this represented a visual chaos and even led to not consciously recognize what was on the canvas. Yet the main reason Ruskin draws heavily on Turner is the artist's ability in achieving vividness in his works and sensitivity to human dramas and suffering rather than adhering to superficial issues.

For Ruskin, the conception of this painting is based on the purest truth as behind the beauty of Turner's skills in light and colour, there is a shadowy touch on the horrors of slavery. What Turner does with his poetic additions to his works corresponds to Ruskin's visual language speaking to the spectators. With his detailed and vivid account, Ruskin gives meaning to Turner's seascape and its intense colours by recreating for his readers his own, emotionally charged response to Turner's painting. For majority, however, what is absent from Ruskin's analysis is any direct reference to the drowning bodies.

"Purple and blue, the lurid shadows of the hollow breakers are cast upon the mist of the night, which gathers cold and low, advancing like the shadow, of death upon guilty ship as it labors amidst the lightening of the sea, its thin masts written upon the sky in lines of blood, girded with condemnation in that fearful hue which signs the sky with horror, and mixes its flaming flood with the sunlight,---and cast far along the desolate heave of the sepulchral waves, incarnadines the multitudinous sea". (Ruskin, 1858, p. 377)

He seems to be highlighting the beauty and truth in art and that probably ignited debates on ignoring the drowning bodies apart from the remark on guilty ship, lines of blood... Aleksandra Piasecka claims that: "Yet, in no place does he mention drowning people painted in the foreground. If it were not for the footnote (She is a slaver, throwing her slaves overboard. The near sea is encumbered with corpses), you would not be aware of the story behind the drama" (2020, p. 18). However, thanks to such ekphrastic elaboration, the metaphorical senses inscribed by the painter could be discovered as it requires a new way of seeing rather than mere looking. Of all the Victorian theorists, Ruskin is the one who puts a strong emphasis on the fact that seeing and representing the world require serious labor. The theory of labor-aesthetics, associated with Ruskin, is founded on slavery, British anti-slavery debates of 1850s. The link between laboring 
bodies and aesthetic art objects could offer a perspective that detaches the reality of slave labor. Truth and beauty can only be attained with a faithful study of nature. Ruskin's realism equals to a visual labor and the reader, like the painter should labor in his act of looking. "At its simplest level, then, the pictorial arts function as a medium for conveying and making permanent truths..." (Landow, 2015, p. 61). What matters is the artist's impressions of the fact as "art does not represent things falsely, but truly as they appear to mankind" (Landow, 2015, p. 64). The great artist is already the one who is able to see farther and more deeply and making the viewers a sharer of those experiences or impressions. Rachel Teukolsky stresses that "Ruskin makes Turner's images speak a perfect visual language of nature, by which small details reveal larger principles" (2009, p. 42). For a profound understanding of nature, concentrating on certain forms of nature or selecting some of them to create a whole pleasant to the beholder's eyes might come short in conveying what is behind the visible world.

As a painter Turner "often touched on the matter of ruins, irreversible flow of time, economic and social deprivation. In this way he managed to reflect in his works a gloomy atmosphere pervading society: the sense of futility of relentless toil and pointlessness of existence..." (Piasecka, 2020, p. 34). During the time Turner lived, landscape painting occupied a remarkable place in Britain with istoria which is the history painting, attracting Turner most. He was aware of the power of literature and poetry; his landscapes deriving subject matter from history were also enriched with symbolism, associationism which set him from his contemporaries and bewildered his viewers. His istoria in a sense meant pictorial interpretation of history. "He subscribed to the notion that the artist, like the poet (and considered himself to have a poetical gift), has freedom of interpretation" (Finley, 1999, p. 4). How history interacts into Turner's pictures could be understood through the titles or attached verses. The Slave Ship is also considered to have been inspired by a real, historical event as its long title suggests. The title Turner gives to his work is a like a short account of the incident (Slavers Throwing Overboard the Dead and Dying Typhoon Coming On) and it is also referred to in the verse that accompanied the painting in its exhibition catalog at Royal Academy in 1840:

\footnotetext{
"Aloft all hands, strike the top-masts and belay;

Yon angry setting sun and fierce-edged clouds

Declare the Typhon's coming.

Before it sweeps your decks, throw overboard

The dead and dying - ne'er heed their chains

Hope, Hope, fallacious Hope!

Where is thy market now?"1
}

The short extract is taken from the collection "Fallacies of Hope" which is regarded as Turner's own attempts of an unfinished and unpublished poem that he began in 1812. Verbal accompaniments written by Turner or poetic verses inspired by the imagery of the slave ship endow a narrative lucidity. "The title and the attached verse-tag may make the general subject clear, yet scholars have attempted to discover more precise sources for the painting's rather

\footnotetext{
${ }^{1}$ https://collections.mfa.org/objects/31102
} 
enigmatic visual content and to fashion an interpretation that seems to fit that content from several perspectives" (Costello, 2012, p. 203). Therefore, it is important to address the specific reference made in the painting to death and suffering which has a historical particularity.

The incident that is frequently associated with Turner's work is the well- known slave ship Zong from 1781. The Zong case involved the murder of one hundred and thirty-two slaves who were thrown overboard so that the captain could claim the insurance money for the slaves as lost property. "The case highlighted the injustice and inhumanity which was so intrinsic to the slave trade and convinced some prominent individuals that the law itself needed to be changed" (Kaye, 2005, p. 7). According to James Walvin's reports from the book The Zong: A Massacre, the LawEthe End of Slavery, a Liverpool registered slave ship, Zong sailed from Africa to Black River in Jamaica in the last weeks of 1781 and its captain had ordered the Africans killed in order to reduce the demand for water and "to ensure that 'marketable' slaves would survive to landfall in Jamaica" (2011, p. 19). As the consequences of the incident quickly turned into a highly visible political and legal issue, the very name- the Zong- entered the demonology of Atlantic slavery and even started to represent the heartless violence of the entire slave system. Rather than a single event, the Zong came to represent a wider story of slave trade and while Turner's The Slave Ship helps to forge a link between the whole barbaric system and Atlantic slave trade, Ruskin's visual prose helps to remind the already debated legacy of the tragic event.

Turner's masterpiece has always been thought as a perfect visual portrayal of the incident although it is not clear that Turner was directly inspired by that tragic ship. The political atmosphere of Britain in 1820s and 30s, anti-slavery acts, books on the history of abolition like Thomas Clarkson's History of the Rise, Progress and Accomplishment of the Abolition of the African Slave Trade could be the prompting reasons for Turner. A great deal of controversy around the painting stood out not only for its dark subject matter but also its exhibition coincided with the first World Anti-Slavery Convention in London. Some even questioned why Turner decided to paint it thirtythree years after the British abolition of slave trade (1807). Britain had a pivotal role in Transatlantic Slave Trade which involved the kidnap and sale of millions of Africans to European traders along the West Coast of Africa and their transport to the 'New World' and even had a controlling and leading position by the end of $18^{\text {th }}$ century. But most of all, for majority it was hard to see what Turner tried to convey at first glance. In Walvin's words, "there is a sailing ship in the distance, about to be engulfed by a typhoon. In the foreground, black people are drowning in a turbulent ocean......And what are those outstretched arms and hands?" (2011, p. 22). After the painting was first exhibited in 1840, it met with widespread criticism and dislike. For the initial reception of the painting Stephen J. May says:

"All the elements of controversy were here: the molten, blood-red sea, the strange ocean creatures devouring human flesh, the slaves' hands groping air above the water while their shackles bobbed in the flood, the sun's rays slashing down the center of the painting, illuminating a severed, elegant, still shackled, human leg. Here was the sea and sky at their most sublime. Here was pure madness - and sheer genius". (2014, p. 13)

Whether by aesthetic concerns or historical realities, the distaste towards the painting creates an urge and curiosity to scrutinize Ruskin who ends his visual narrative with those remarks: 
"if I were reduced to rest Turner's immortality upon any single work, I should choose this. Its daring conception -ideal in the highest sense of the word -is based on the purest truth..." (Ruskin, 1858, p. 377)

According to Ruskin, painters are categorized as either great masters, represented by Turner or imitators epitomized by Nicolas Poussin (Piasecka, 2020, p. 32). The distinction is based on his theories of truth, nature and imagination. What puts an artist in high esteem is not the quality of creating lifelike pictures but reflections of mind. The aim and concept of Modern Painters is so indistinguishable from his advocacy of Turner and his preoccupation with "truth" in representation. Ruskin's concept of truth in art does not involve perfect transcription of nature but rather presents a strong criticism of imitation. At this point it is worth pointing to the link between Turner and how his art corresponds to that perception. Turner's realism is at odds with ordinary perception and public taste but proposes a visual intensity that is not isolated from thought and feeling. Ruskin's concern is with "the nature of ideas and subjective processes, approaching the question of visual representation by establishing a prior theoretical framework of mental representation..." (Garratt, 2010, p. 88). The crucial part of Ruskin's aesthetics of realism identifies truthfulness with an ideational structure in the mind rather than mimetic production.

“(...) the problem of truth is intimately bound up with Ruskin's notion of beauty and its perception. The beautiful, according to the Victorian critic, expresses divine attributes. It is neither mechanical reception nor an abstract concept but a complex, gradual process. Beauty originates from the sensual impression which first stirs up emotions and subsequently awakens love for the perceived object along with the desire for identification with it. Finally, it leads to the discovery of the higher idea behind it..." (Piasecka, 2020, p. 34-35).

Ruskin's belief on the importance of an exceptional imagination enabling the artist to penetrate the essence of reality, possessing the capacity to see clearly with an acute sense of observation prompt him to impart his readers through the descriptions of works of art in Modern Painters as he not only evokes mental images in minds but also teaches how to approach paintings. Therefore, conveying emotions with a vivid language reveal Ruskin's emphasis on the interconnection between the two arts, poetry and painting and even making a clear point on his advocacy of painters. The wonderful capacity of the visual arts to communicate fact, feeling, and belief enables them to have a profound influence on the lives of men. Anchoring Leonard Barkan's "Making Pictures Speak: Renaissance Art, Elizabethan Literature and Modern Scholarship", the speaking picture then, whatever it lacks in clarity, it more than makes up for an imaginative force. To move from poetry to mimesis to speaking picture is to promise something like a totalizing experience, one that embraces both eyes and ears (1995, p. 327).

Turner's work reveals a keen interest in capturing the nature's effects of light and colour, yet his vision also has much to do with undetected meanings lingering beneath the surface of his art. Although the latter raised problems of visual comprehension, using figurative and metaphorical expressions meant broadening the imaginative dimensions of his art. According to Eric Shanes, Turner had an unusually connective mind, he also "imbued many of his works with associative devices commonly encountered in poetry" (2008, p. 19) like allusions, subtle hints at specific 
meanings, similes or direct comparisons between forms, metaphors... (2008, p. 19). Turner's lifelong idealism and near abstraction is also very much identified with platonic forms, ideal beauties, yet the representations of human figures especially in landscape and marine painting state the central moral contrast of his entire art as far as humanity is concerned: "the world around us may be immense, beautiful, ugly, peaceful, serious or whatever, but humankind is small, vain and of exceedingly limited strength within that surround" (2008, p. 27). Overcoming the forces of nature in an indifferent universe is nothing but a 'fallacy of hope'.

\section{CONCLUSION}

Turner brings slave trade to a wider audience with his painting helping to expose the barbarity of the trade and dispel the assumptions fostered in Britain to justify slavery or make it look legitimate and profitable. Turner's visual representation, its verbal references and the background of the incident in the picture already make a statement yet it is possible to add more to the topic by embedding the painting into a historical background and introducing Ruskin's interpretation on the imagery. Turner's visual narratives or poetic canvases in other words, denote critical thinking and present a musing discourse upon material realities. Thanks to Ruskin's narrative which goes beyond mere depiction, the painting raises to a level of history, slave trade, and human tragedy. What Ruskin does through word painting or ekphrasis does not just contribute to the popularity of the painting, in a way he recreates the painting for readers and elicits an intense emotional impact with a visual, verbal and critical appreciation. Turner's imagery which is seemingly devoid of detail, communicates in Ruskin's expressive composition and account. In that sense, rather than simply looking at the visual, finding its equivalence in verbal terms enriches in narratives in an aesthetic way such in Ruskin's meditation which accentuates the vivid portrayal to such an extent that, prompting the viewers to become aware of the horrors of slavery is made possible through a commenting and interpreting ekphrastic voice.

\section{WORKS CITED}

Barkan, Leonard (1995). “Making Pictures Speak: Renaissance Art, Elizabethan Literature, Modern Scholarship." Renaissance Quarterly, vol. 48, no. 2, pp. 326-351.

Bradley, J.L. (2002). The Critical Heritage: John Ruskin. Ed. London and New York: Routledge. Costello, Leo (2012). J. M. W. Turner and the Subject of History. Surrey: Ashgate Publishing,

Döring, Tobias (1997). "Turning the colonial gaze”, Third Text, vol. 11, n. 38, pp. 314, DOI: $10.1080 / 09528829708576654$

Finley, Gerard (1999). Angel in the Sun: Turner's Vision of History. McGill Queen's University Press. Fisher, Judith L. (1996). "Magnificent or Mad? Nineteenth-Century Periodicals and the Paintings of Joseph Mallord William Turner." Victorian Periodicals Review, vol. 29, no. 3, pp. 242-260.

Garratt, Peter (2010). Victorian Empiricism: Self, Knowledge, and Reality in Ruskin, Bain, Lewes, Spencer and George Elliot. Rosemnont Publishing \& Printing Corp.

Hunt, John Dixon (1978). “Ut Pictura Poesis, the Picturesque, and John Ruskin.” MLN, vol. 93, no. 5, pp. 794-818. 
Kaye, Mike (2005). 1807-2007: Over 200 years of campaigning against slavery, Anti-Slavery International.

Landow, George P. (2015). Aesthetic and Critical Theory of John Ruskin. Princeton University Press,

May, Stephen J. (2014). Voyage of The Slave Ship: J.M.W. Turner's Masterpiece in Historical Context. North Carolina: McFarland\&Company, Inc., Publishers.

McCoubrey, John (1998). "Turner's Slave Ship: Abolition, Ruskin, and reception”, Word E Image, vol. 14, no. 4, pp. 319-353, DOI: 10.1080/02666286.1998.10443961

Moretti, Giampiero (2016). "Romanticism and Impressionism. A path between Turner and

Monet". Lebenswelt: Aesthetics and Philosophy of Experience, 10.13130/2240-9599/7306.

Munsterberg, Marjorie (2009). “Ruskin's Turner: The Making of a Romantic Hero." The British Art Journal, vol. 10, no. 1, pp. 61-71.

Piasecka, Aleksandra (2020). "John Ruskin's word paintings in the context of his principle of clear vision as well as the biblical and rhetorical tradition". Journal of Education Culture and Society, vol. 2, no.1, pp. 31-49. https://doi.org/10.15503/jecs20111.31.49

Ruskin, John (1858). Modern Painters: pt. 1. Of general principles. Pt. 2. Of Truth of Water. New York: Wiley\&Halsted,

Ruskin, John, Edward T. Cook, and Alexander D. O. Wedderburn (1903). The Works of John Ruskin. Ballantyne, Hanson \& Co.

Shanes, Eric (2008). The Life and Masterworks of J. M. W. Turner. New York: Park Stone Press International.

Teukolsky, Rachel (2009). The Literate Eye: Victorian Art Writing and Modernist Aesthetics. Oxford: Oxford University Press,

Turner, William. Slave Ship (Slavers Throwing Overboard the Dead and Dying, Typhoon Coming On). Museum of Fine Arts, Boston, United States. https://collections.mfa.org/objects/31102

Walvin, James (2011). The Zong: A Massacre, the Law and the End of Slavery. Yale University Press,

Wettlaufer, Alexandra K. (2000). “The Sublime Rivalry of Word and Image: Turner and Ruskin Revisited." Victorian Literature and Culture, vol. 28, no. 1, pp. 149-169.

Wettlaufer, Alexandra K. (2003). In the Mind's Eye: The Visual Impulse in Diderot, Baudelaire and Ruskin. Amsterdam: Rodopi.

Whelchel, Harriet (1993). Ed. John Ruskin and the Victorian Eye. New York: Harry N. Abrams.

Wilton, Andrew (1980). Turner and the Sublime. London: British Museum Publications.

Ziff, Jerrold (1964). "J. M. W. Turner on Poetry and Painting." Studies in Romanticism, vol. 3, no. 4, pp. 193-215. 
